\title{
Analisis Pengaruh Penempatan Balok Anak pada Perencanaan Pelat Lantai Gedung Toko Satu Sama
}

\author{
Karel Agung *1, Jonie Tanijaya ${ }^{* 2}$, Olan Jujun Sanggaria *3 \\ *1 Mahasiswa Program Studi Teknik Sipil, Universitas Kristen Indonesia Paulus Makassar, \\ Indonesia karelagung00@gmail.com \\ *2,3 Dosen Program Studi Teknik Sipil, Universitas Kristen Indonesia Paulus Makassar, Indonesia \\ jonie.tanijaya@gmail.com dan olanjujun@gmail.com
}

Corresponding Author: olanjujun@gmail.com

\begin{abstract}
Abstrak
Salah satu model perencanaan struktur yang dapat dipakai untuk mengefisienkan struktur gedung ialah dengan menambahkan balok anak. Berdasarkan asumsi tersebut maka tulisan ini dibuat untuk menganalisis pengaruh penempatan balok anak pada struktur lantai gedung untuk mengetahui besarnya efisiensi yang terjadi terhadap tebal pelat dan material beton bertulang yang digunakan. Pada kasus perencanaan gedung Toko Satu Sama di Jl. Perintis Kemerdekaan Kota Makassar denah lantai diberi satu balok anak pada arah-x dan menghasilkan tebal pelat $150 \mathrm{~mm}$. Denah lantai tersebut direncanakan ulang dengan membuat denah lantai tanpa balok anak, denah lantai dengan balok anak arah-y dan denah lantai dengan balok anak arah-x dan y. Momen lentur yang terjadi pada pelat lantai dihitung menggunakan metode PBI 1971, namun dengan tetap mempertimbangkan ketentuan terbaru dalam SNI 2847, 2019. Hasil perhitungan menunjukkan bahwa denah lantai dengan pola penempatan balok anak arah-x dan y $(\mathrm{h}=120$ $\mathrm{mm}$ ) dapat mengefisienkan pelat sebesar $20 \%$ dari tebal pelat dengan pola penempatan balok anak arah-x. Sejalan dengan itu kebutuhan beton pun dapat diefisienkan sebesar 15,359\% $\left(12,284 \mathrm{~m}^{3}\right)$. Sekalipun memiliki kebutuhan tulangan yang lebih banyak, pola penempatan balok anak arah-x dan y merupakan pola yang paling efisien.
\end{abstract}

\section{Kata kunci : Beton Bertulang, Pelat, Balok Anak}

\begin{abstract}
One model of structural planning that can be used to make the building structure efficient is to add the secondary beams. Based on these assumptions, this paper is made to analyze the effect of placing secondary beams on the floor structure of the building to determine the efficiency that occurs to the thickness of the slab and the reinforced concrete material used. In the case of planning the Toko Satu Sama building on Jl. Perintis Kemerdekaan City Makassar floor plan is given one secondary beam on the $x$-direction and produces a plate thickness of 150 $\mathrm{mm}$. The floor plan is re-planned by making a floor plan without secondary beams, a floor plan with $y$-directional secondary beams and a floor plan with $x$-and-y secondary beams. The bending moment that occurs on the floor plate is calculated using the 1971 PBI method, but still considering the latest provisions in SNI 2847, 2019. The results of the calculation showed that the floor plan with the pattern of placement of secondary beams in the direction of $x$ and $y$ $(h=120 \mathrm{~mm})$ can streamline the plate by $20 \%$ of the thickness of the plate with the pattern of placement of the secondary beam in the direction of $x$. In line with that, concrete needs can be effective by 15,359 \% (12,284 m3). Even if it has more reinforcement needs, the pattern of placement of secondary beams in the direction of $x$ and $y$ is the most efficient pattern.
\end{abstract}

Keywords: Reinforced Concrete, Plates, Secondary Beams 


\section{PENDAHULUAN}

Salah satu cara yang dapat dipakai untuk membuat struktur gedung lebih efisien ialah dengan menambahkan elemen balok anak pada struktur gedung khususnya pada gedung dengan bentang pelat yang cukup panjang. Penempatan balok anak ini membagi luasan pelat lantai gedung, sehingga pelat yang sebelumnya memiliki bentangan yang cukup panjang dengan adanya balok anak panjang pelat diperkecil. Dengan begitu tebal pelat menjadi lebih efisien.

Secara umum paling tidak ada tiga kondisi di mana balok anak biasa digunakan. Pertama, tebal pelat yang lebih besar dari tebal minimum pelat (> $125 \mathrm{~mm}$ ). Kedua, dimensi pelat di atas $(5 \times 5) \mathrm{m}$. Ketiga, panjang bentang pelat lebih dari $4 \mathrm{~m}$. Berdasarkan tiga kondisi tersebut dilakukan penilaian terhadap data perencanaan pelat lantai 2 gedung Toko Satu Sama di Jl. Perintis Kemerdekaan km. 12, Makassar. Dari data tersebut dapat diketahui bahwa pelat lantai gedung tersebut terdiri dari berbagai ukuran, yakni (9200 x 6475) $\mathrm{mm},(9200 \times 9000) \mathrm{mm},(9200 \times 8000) \mathrm{mm},(7800 \times 6475) \mathrm{mm},(7800 \times 9000) \mathrm{mm},(7800 \times 8000) \mathrm{mm}$. Semuanya memiliki ukuran yang lebih besar dari $(5000 \times 5000) \mathrm{mm}$, berarti kondisi kedua terpenuhi. Semua pelat tersebut memiliki panjang bentang lebih dari $4 \mathrm{~m}$, berarti memenuhi kondisi ketiga. Dengan bentangan pelat yang cukup panjang seperti itu akan menghasilkan pelat dengan ketebalan yang cukup besar. Pada kondisi ini perencanaan pelat lantai gedung Toko Satu Sama dapat dirancang dengan menambahkan balok anak untuk mengefisienkan tebal pelatnya. Sejalan dengan maksud itu, konsultan perencana menambahkan balok anak arah-x pada denah lantai tersebut dan menghasilkan tebal pelat $150 \mathrm{~mm}$. Ketebalan tersebut masih lebih besar dari syarat pertama $(120 \mathrm{~mm})$. Berdasarkan kondisi tersebut maka dilakukan pemodelan denah lantai dengan pola penempatan balok anak yang berbeda. Hal itu dilakukan untuk mencari tahu seberapa besar pengaruh variasi peletakan balok anak terhadap efisiensi dimensi penampang pelat lantai gedung dan efisiensi kebutuhan material beton bertulang yang digunakan.

Dalam SNI 2847:2019 Tabel 9.3.1.1. mengatur tinggi minimum balok nonprategang yang bisa digunakan jika nilai lendutan tidak diperhitungkan. Berdasarkan tabel tersebut penentuan tinggi minimum balok dilakukan berdasarkan kondisi perletakannya. Menurut Vis dan Gideon, lebar balok induk, $b$, diperkirakan sebesar $1 / 2 h$ sampai $2 / 3 h$. (Vis \& Kusuma, 1993) [1]. Pada umumnya dimensi balok anak dibuat lebih kecil dari balok induk. Dimensi balok anak dibuat lebih kecil dari balok.

Besarnya momen ultimit yang terjadi pada balok dapat dihitung dengan menggunakan rumus momen pendekatan pada SNI 2847:2019 Tabel 6.5.2. Untuk menghitung gaya geser yang timbul akibat pembebanan gravitasi nilai $(V u)$ dapat dihitung berdasarkan Tabel 6.5.4 pada SNI 2847:2019 Tabel 6.5.4.

Pendesaian tulangan utama balok dilakukan berdasarkan nilai faktor momen pikulnya $(K)$ terhadap faktor momen pikul maksimal $\left(K_{\text {maks }}\right)$.

Jika, $K \geq K_{\text {maks }}$ maka balok tersebut didesain untuk tulangan rangkap.

Jika, $K \leq K_{\text {maks }}$ maka balok tersebut didesain untuk tulangan tunggal.

$$
\begin{aligned}
K_{\text {maks }} & =\frac{382,5 \beta_{1}\left[600+f_{y}-225 \beta_{1}\right] \dot{f} c}{\left[600+f_{y}\right]} \\
K & =\frac{M_{u}}{\emptyset . b . d^{2}}
\end{aligned}
$$

Menghitung luas tulangan minimum dan maksimum:

$$
\begin{aligned}
& A_{s \min }=\rho_{\text {min }} \cdot b . d \\
& A_{s \max }=\rho_{\text {max }} \cdot b \cdot d
\end{aligned}
$$

Syarat: $A_{s \min }<A_{s}<A_{s \max }$

Kontrol $M_{d}$ harus $\geq M_{u}$ :

Menghitung momen nominal $\left(M_{n}\right)$ :

$$
M_{n}=A_{s} \cdot f_{y} \cdot\left(d-\frac{a}{2}\right)
$$


Menghitung momen desain $\left(M_{d}\right)$ :

$$
M_{d} \quad=\phi M_{n}
$$

Perhitungan tulangan geser $\left(V_{u}\right)$ :

Pemeriksaan kecukupan penampang untuk memikul geser:

$$
V_{u} \leq \varnothing\left(V_{c}+0,66 \sqrt{f_{c}^{\prime}} b_{w} d\right)
$$

Menghitung kebutuhan tulangan geser:

Jika $V_{\mathrm{u}}<1 / 2 \varnothing V_{c}$ maka tulangan geser tidak diperlukan.

Jika $1 / 2 \varnothing V_{c}<\mathrm{V}_{\mathrm{u}}<\varnothing V_{c}$ maka dipasang tulangan geser minimum.

Jika $\mathrm{V}_{\mathrm{u}}>\emptyset V_{c}$ maka dipasang tulangan geser.

Secara sederhana tipe pelat dibedakan melalui rasio bentang sisi panjang (ly) terhadap sisi lebarnya (lx). Jika, $l y / l x>2$ maka pelat tersebut tergolong pelat satu arah. Penentuan tebal pelat satu arah menggunakan rumus 1/24 untuk kondisi tumpuan satu ujung menerus dan 1/28 untuk kondisi tumpuan dua ujung menerus. Jika, $l y / l x \leq 2$ maka pelat tersebut tergolong pelat dua arah. Dalam menghitung tebal pelat minimum pada setiap pelat dua arah dipakai rumusan dalam SNI 2847, 2019 Tabel 8.3.1.2. Rumusan tersebut mensyaratkan untuk mengetahui terlebih dahulu nilai rata-rata dari rasio kekakuan lentur penampang balok terhadap kekakuan lentur pelat $\left(\alpha_{f m}\right)$. Perhitungan tersebut dilakukan tersendiri dan dari semua hasil perhitungan yang dilakukan pada berbagai ukuran dan kondisi tumpuan pelat diketahui bahwa nilai $\alpha \mathrm{fm}>2,0$. Karena itu, tebal pelat dihitung dengan rumus:

$$
h_{f}=\frac{l_{n}\left(0,8+\frac{f y}{1400}\right)}{36+9 \beta}
$$

Besarnya momen yang terjadi dihitung dengan metode PBI 1971 yang disesuaikan dengan jenis perletakannya.

$$
M_{i}=0,001 \times W_{u} \times l_{x}^{2} \times C_{\mathrm{i}}
$$

Kontrol Momen: $M u$ harus $\leq \varnothing M n$

Dilakukan sesuai persamaan (5) dan (6).

Kontrol Geser: $V u \leq \varnothing V c$

Nilai $V u$ dihitung sesuai persamaan (7).

Nilai $\varnothing V c$ dihitung dengan cara:

$$
\varnothing V_{c}=\varnothing \frac{1}{6} \sqrt{f_{c}^{\prime}} \times b \times d
$$

Dalam rangka menganalisis sejauh mana pengaruh balok anak pada suatu struktur gedung beberapa pihak telah memberikan sumbangsinya masing-masing lewat penelitian dan tulisan ilmiah yang dibuat antara lain. Bakti Setiyadi \& Hengky Pradoto, 1996 "Studi Komparasi Perilaku Balok Grid dan Balok Konvensional pada Struktur Pelat Lantai Bangunan Gedung" [2]. Dari hasil penelitian tersebut diketahui bahwa penggunaan balok anak dapat menambah kekakuan struktur sekaligus dapat mengefisienkan biaya material bangunan. Agung Dedy Purnomo \& Sugiharjo, 2000 "Analisis Pengaruh Penempatan Balok Anak Terhadap Portal Komposit Baja-Beton dengan Metode LRFD'86” [3].. Berdasarkan hasil penelitian tersebut diketahui bahwa dari variasi penempatannya diperoleh hasil bahwa balok anak yang ditempatkan sejajar dengan balok induk yang terpendek merupakan penempatan yang terbaik, karena dapat mengurangi dimensi struktur lainnya. Julistyana Tistogondo, 2005 "Studi Perbandingan Penggunaan Balok Anak Konstruksi Propped pada Bangunan Tingkat Dua dengan Variasi Jarak Balok dan Portal dari Segi Teknik dan Biaya" [4].. Berdasarkan hasil dari penelitian tersebut diketahui bahwa pemakaian balok anak selain diperhitungkan untuk kestabilan struktur juga untuk mengurangi biaya pembangunan struktur. Ndaru Prasetya Wibawa \& 
Kismana, 2005 "Balok Anak sebagai Beban Terpusat dan sebagai Struktur Monolit, dan Pengaruhnya Terhadap Respon Struktur Beton Bertulang" [5].. Berdasarkan hasil penelitian tersebut diketahui bahwa akibat beban gravitasi, pembebanan balok anak sebagai beban terpusat menghasilkan momen dan gaya geser akibat beban mati dan beban hidup menjadi lebih besar, dibandingkan pembebanan balok anak sebagai satu kesatuan struktur. M. Budiyawan \& Purnawan Yulandaru, 2006 "Pengaruh Variasi Peletakan Balok Anak Terhadap Volume Struktur Pelat dan Balok" [6].. Berdasarkan hasil penelitian tersebut diketahui bahwa variasi struktur yang mempunyai satu balok anak arah-x dan arah-y lebih ekonomis karena ketebalan teoritis pelat tersebut mendekati tebal minimum yang disyaratkan yakni $120 \mathrm{~mm}$. Erik Setiawan, dkk 2015. "Studi Penggunaan Balok Anak pada Struktur Pelat Beton Bertulang" [7]. Berdasarkan hasil penelitian tersebut diketahui bahwa penggunaan balok anak pada struktur bangunan adalah untuk membantu mengurangi tebal pelat lantai $(>125 \mathrm{~mm}$ ) dan luasan efektif pelat untuk penggunann balok anak ialah dengan luasan di atas (5 x 5) $\mathrm{m}^{2}$. Ranu Sakti Ilahi Chilk, 2019. "Pengaruh Balok Anak Terhadap Ketebalan Pelat Lantai Masjid Lheu Kabupaten Aceh Besar" [8]. Dari hasil penelitian diketahui bahwa pola penggunaan balok anak yang menghasilkan ketebalan pelat yang paling optimal ialah balok anak dalam arah-x dan arah-y. I Gusti Ngurah Eka Partama, 2019. "Penentuan Tebal Pelat Lantai Gedung yang Ditumpu pada Keempat Sisinya sesuai SNI 2847:2013" [9]. Berdasarkan hasil penelitian diketahui bahwa variasi dimensi panel pelat memberikan pengaruh yang signifikan terhadap ketebalan pelat. Audy Nadyaputri Majid, dkk, 2019. "Analisis Pengaruh Dimensi Balok Anak Terhadap Momen Lentur pada Pelat dengan Metode Amplop dan Metode Elemen Hingga" [10]. Berdasarkan hasil penelitian tersebut menujukkan bahwa nilai momen pada Metode Amplop yang tidak memasukkan dimensi balok anak lebih kecil dibandingkan dengan nilai momen menggunakan Metode Elemen Hingga, sehingga penggunaan Metode Elemen Hingga lebih aman digunakan dalam perhitungan struktur. Tahan, 2019. "Pengaruh Kekuatan Balok Induk Terhadap Dimensi Balok Anak pada Beton Bertulang" [11]. Berdasarkan hasil penelitian diketahui bahwa balok induk dan balok anak harus mempunyai dimensi tinggi yang sama tetapi lebar balok anak lebih kecil yakni 12,5\% kurangnya dari lebar dari balok induk dengan beban yang dipikulnya $70 \%$ dari beban maksimum.

\section{METODOLOGI}

Penelitian ini dilakukan dengan langkah-langkah seperti dalam bagan alir di bawah :

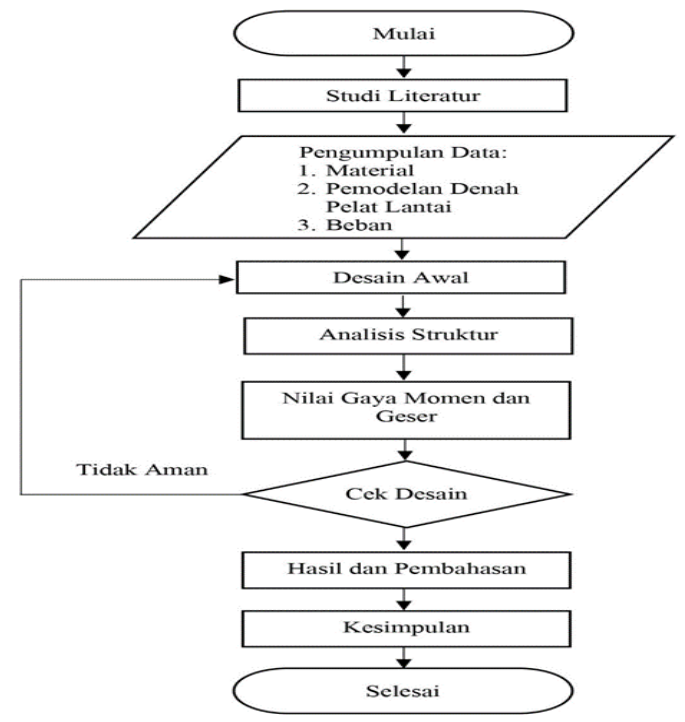

Gambar 1. Bagan Alir Pengolahan dan Analisis Data 
Adapun data bangunan dan mutu material adalah sebagai berikut:

1. Tipe bangunan ialah supermarket

2. Dimensi elemen struktur :

- Balok induk arah-y : : 500 x $900 \mathrm{~mm}$

- Balok induk arah-x : $400 \times 800 \mathrm{~mm}$

3. Dimensi kolom utama $: 650 \times 850 \mathrm{~mm}$

4. Mutu beton, $f^{\prime} c=30 \mathrm{Mpa}(\mathrm{K}-350)$

5. Mutu tulangan, $f_{y}=420 \mathrm{MPa}$

Pembebanan yang digunakan ialah :

1. Beban hidup $\quad=600 \mathrm{~kg} / \mathrm{m}^{2}$ (beban grosir sesuai SNI 1727,2020 )

2. Beban tambahan $=120 \mathrm{~kg} / \mathrm{m}^{2}$

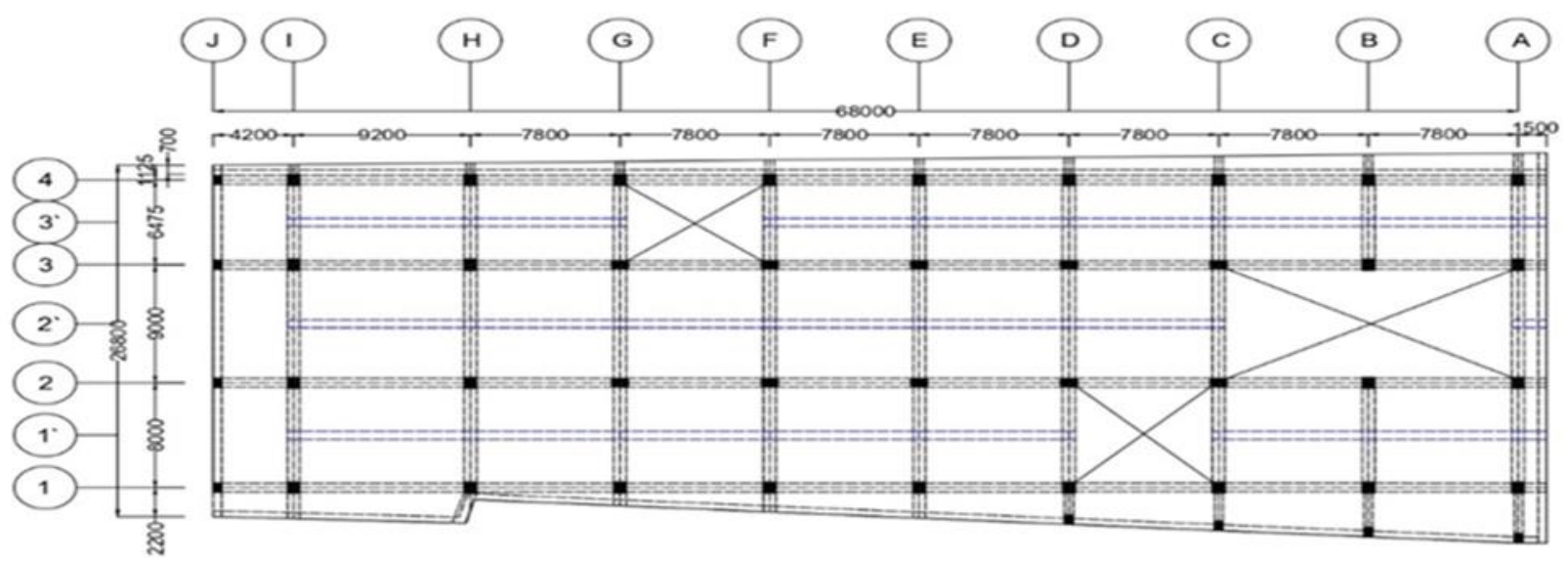

Gambar 2. Denah Lantai 2 Perencanaan Gedung Toko Satu Sama

Pemodelan denah lantai dengan variasi penempatan balok anak :

1. Pola I

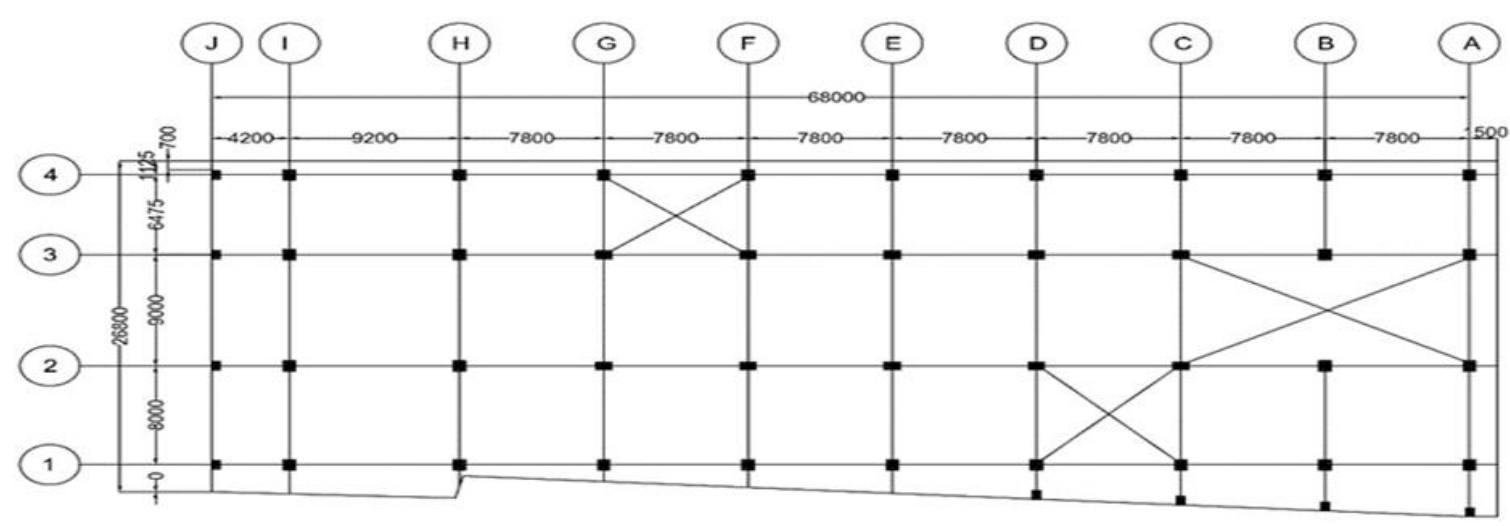

Gambar 3. Denah Lantai Tanpa Balok Anak (Pola I) 
2. Pola II

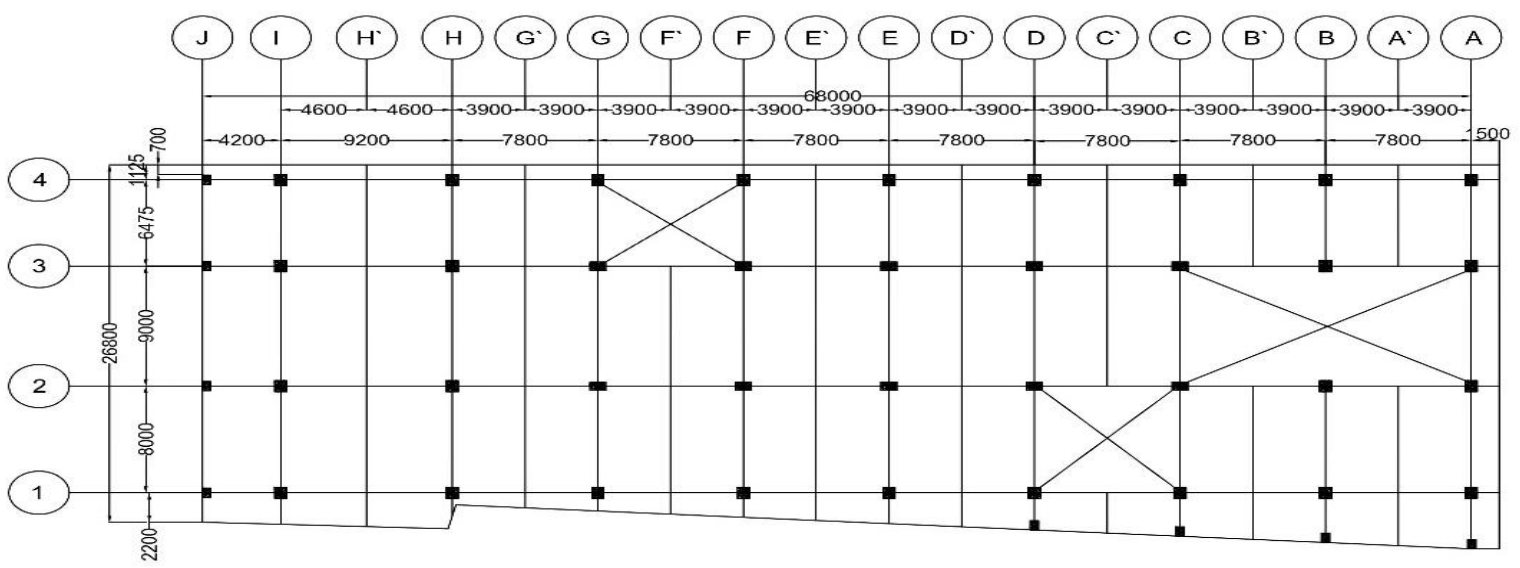

Gambar 4. Denah Lantai dengan Balok Anak Arah-Y (Pola II)

3. Pola III

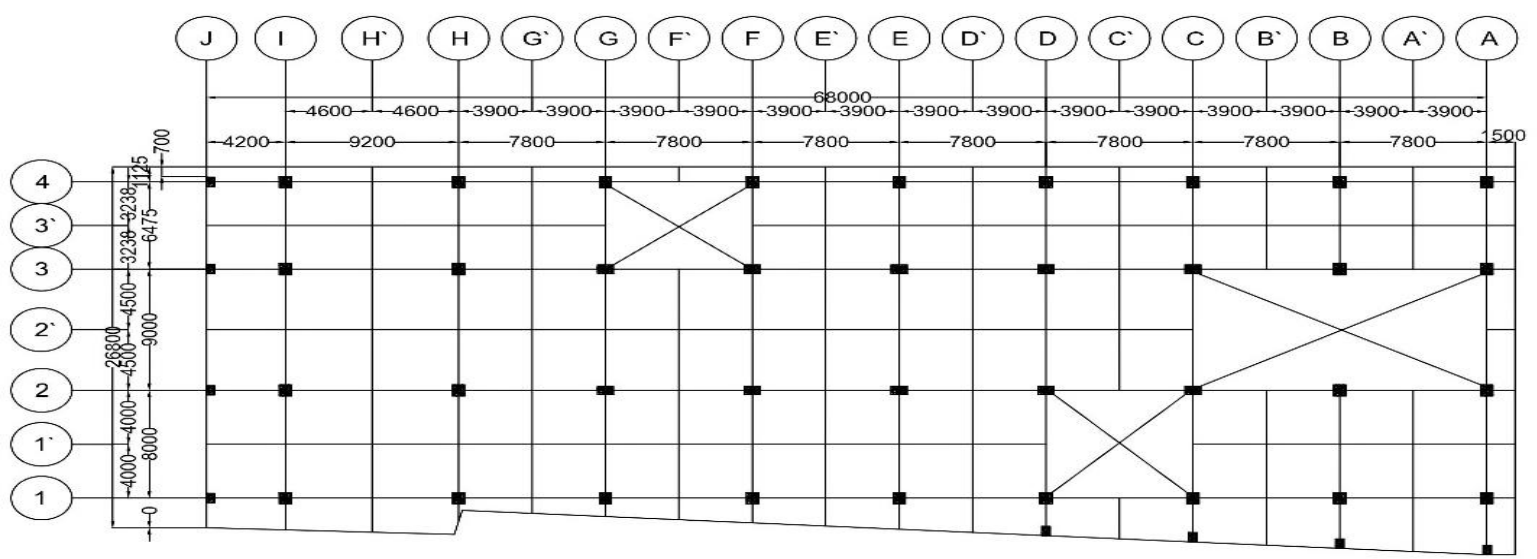

Gambar 5. Denah Lantai dengan Balok Anak Arah-X dan Y (Pola III)

\section{HASIL DAN PEMBAHASAN}

Perencanaan dimensi dan pendesainan tulangan pada balok anak dan pelat dilakukan pada satu tipe pelat yang dipilih untuk mewakili keseluruhan denah lantai yang kemudian hasilnya akan diperbandingkan dengan denah lantai yang lain termasuk pola denah konsultan perencana. Pelat yang dimaksud ialah H-I \& 2-3, yang merupakan pelat dengan ukuran terluas, $(9200 \times 9000) \mathrm{mm}^{2}$.

\section{Analisis Denah Lantai Pola I}

Berdasarkan perhitungan ketebalan pelat pada modul terbesar diperoleh ketebalan pelat $220 \mathrm{~mm}$. 
Tabel 1. Pendesainan Tulangan untuk Denah Lantai Tanpa Balok Anak

\begin{tabular}{ccccccccc}
\hline & $C_{\mathrm{i}}$ & $W_{u}$ & $M_{u}$ & $d$ & $K$ & $a$ & $A_{s, u}$ & \multirow{2}{*}{ Dipakai } \\
\cline { 3 - 7 } & & $\mathrm{Kg}$ & $\mathrm{Kgm}$ & $\mathrm{mm}$ & $\mathrm{MPa}$ & $\mathrm{mm}$ & $\mathrm{mm}^{2}$ & \\
\hline Tumpuan-x & 53,4 & 1737,6 & 7515,815 & 195 & 2,19616 & 17,587 & 1067,80 & D10-70 \\
\hline Lapangan-x & 21,8 & 1737,6 & 3068,254 & 195 & 0.89656 & 6,981 & 423,847 & D10-180 \\
\hline Tumpuan-y & 52,4 & 1737,6 & 7375,069 & 195 & 2,15504 & 17,242 & 1046,833 & D10-70 \\
\hline Lapangan-y & 21 & 1737,6 & 2955,658 & 185 & 0,95955 & 7,098 & 430,926 & D10-180 \\
\hline
\end{tabular}

Tabel 2. Kontrol Momen dan Gaya Geser

\begin{tabular}{cccccccc}
\hline & $A_{s \text { baru }}$ & $a$ & $\phi M_{n}\left(M_{u} \leq \phi M_{n}\right)$ & $L_{n}$ & $q_{u}$ & $V_{u}$ & \multicolumn{2}{c}{$\phi V_{c}\left(V_{u} \leq \phi V_{c}\right)$} \\
\cline { 2 - 8 } & $\mathrm{mm}^{2}$ & $\mathrm{~mm}$ & $\mathrm{Kgm}$ & $\mathrm{mm}$ & $\mathrm{kg}$ & $\mathrm{Kg}$ & $\mathrm{Kg}$ \\
\hline Tumpuan-x & 1121,429 & 18,471 & $7874,566(\mathrm{OK})$ & 8600 & 1737,6 & 7471,68 & $16020,885(\mathrm{OK})$ \\
\hline Tumpuan-y & 1121,429 & 18,471 & $7874,56(\mathrm{OK})$ & 8700 & 1737,6 & 7558,56 & $16020,885(\mathrm{OK})$ \\
\hline
\end{tabular}

\section{Analisis Denah Lantai Pola II}

Dimensi balok anak dihitung dan diambil dimensi yang lebih besar dari hasil hitung, yakni 30/65.

Tabel 3. Pendesainan Tulangan dan Kontrol Momen Balok Anak Pola II

\begin{tabular}{cccccccc}
\hline & $M_{u}$ & $K$ & $a$ & $A_{s, u}$ & $n$ & Dipakai & $\begin{array}{c}M_{\mathrm{d}} \\
\left(M_{u} \leq \phi M_{n}\right)\end{array}$ \\
\cline { 2 - 8 } & $\mathrm{Nmm}$ & $\mathrm{MPa}$ & $\mathrm{mm}$ & $\mathrm{mm}^{2}$ & & & $\mathrm{Nmm}$ \\
\hline Tumpuan & 459489550 & 5,35000 & 134,325 & 2446,637 & 6,44 & $7 \mathrm{D} 22$ & $493604607,4(\mathrm{OK})$ \\
\hline Lapangan & 315899064 & 3,67812 & 88,257 & 1607,535 & 4,2 & $5 \mathrm{D} 22$ & $367553611,8(\mathrm{OK})$ \\
\hline
\end{tabular}

Tabel 4. Pendesainan Tulangan Geser pada Balok Anak Pola II

\begin{tabular}{|c|c|c|c|c|c|c|c|}
\hline & $V_{u d}$ & $A_{v} / s$ & $A_{v}$ & $s_{1}$ & $s_{2}$ & $s_{3}$ & Dipakai \\
\hline & $\mathrm{N}$ & & $\mathrm{mm}^{2}$ & $\mathrm{~mm}$ & $\mathrm{~mm}$ & $\mathrm{~mm}$ & \\
\hline Tumpuan & 252133,16 & 0,307 & 157 & 511,401 & 369,5 & 600 & D10-300 \\
\hline Lapangan & 152688,7 & 0,292 & 157 & 537,671 & 369,5 & 600 & D10-350 \\
\hline
\end{tabular}

Berdasarkan perhitungan pada modul terbesar diperoleh ketebalan pelat $180 \mathrm{~mm}$. 
Tabel 5. Pendesainan Tulangan untuk Denah Lantai Pola II

\begin{tabular}{ccccccccc}
\hline & $C_{\mathrm{i}}$ & $W_{u}$ & $M_{u}$ & $d$ & $K$ & $a$ & $A_{s, u}$ & \multirow{2}{*}{ Dipakai } \\
\cline { 3 - 7 } & & $\mathrm{Kg}$ & $\mathrm{Kgm}$ & $\mathrm{mm}$ & $\mathrm{MPa}$ & $\mathrm{mm}$ & $\mathrm{mm}^{2}$ & \\
\hline Tumpuan-x & 83 & 1622,4 & 2849,389 & 155 & 1,31779 & 8,229 & 499,588 & \multirow{2}{*}{ D10-150 } \\
\hline Lapangan-x & 40,6 & 1622,4 & 1393,797 & 155 & 0.64461 & 3,969 & 324 & \multirow{2}{*}{ D10-240 } \\
\hline Tumpuan-y & 57 & 1622,4 & 1956,809 & 155 & 0,90499 & 5,602 & 340,13 & D10-230 \\
\hline Lapangan-y & 12 & 1622,4 & 411,960 & 145 & 0,21771 & 1,243 & 324 & \multirow{2}{*}{ D10-240 } \\
\hline
\end{tabular}

Tabel 6. Kontrol Momen dan Gaya Geser

\begin{tabular}{cccccccc}
\hline & $A_{s \text { baru }}$ & $a$ & $\phi M_{n}\left(M_{u} \leq \phi M_{n}\right)$ & $L_{n}$ & $q_{u}$ & $V_{u}$ & $\phi V_{c}\left(V_{u} \leq \phi V_{c}\right)$ \\
\cline { 2 - 8 } & $\mathrm{mm}^{2}$ & $\mathrm{~mm}$ & $\mathrm{Kgm}$ & $\mathrm{mm}$ & $\mathrm{kg}$ & $\mathrm{Kg}$ & $\mathrm{Kg}$ \\
\hline Tumpuan-x & 523,333 & 8,620 & $2882,038(\mathrm{OK})$ & 8600 & 1622,4 & 6976,32 & $12734,550(\mathrm{OK})$ \\
\hline Tumpuan-y & 341,304 & 5,621 & $1963,441(\mathrm{OK})$ & 4200 & 1622,4 & 3407,04 & $12734,550(\mathrm{OK})$ \\
\hline
\end{tabular}

\section{Analisis Denah Lantai Pola III}

Dimensi balok dihitung dan diambil dimensi yang lebih besar dari hasil hitung, yakni 30/55.

Tabel 7. Pendesainan Tulangan dan Kontrol Momen Balok Anak Pola III

\begin{tabular}{cccccccc}
\hline & $M_{u}$ & $K$ & $a$ & $A_{s, u}$ & $n$ & Dipakai & $M_{\mathrm{d}}\left(M_{u} \leq \phi M_{n}\right)$ \\
\cline { 2 - 8 } & $\mathrm{Nmm}$ & $\mathrm{MPa}$ & $\mathrm{mm}$ & $\mathrm{mm} 2$ & & & Nmm \\
\hline Tumpuan (BA-Y) & 30160,619 & 5,18848 & 106,672 & 1942,950 & 5,1 & $6 \mathrm{D} 22$ & $345906606,8(\mathrm{OK})$ \\
\hline Lapangan (BA-Y) & 20735,426 & 3,21167 & 66,049 & 1203,039 & 3,2 & $4 \mathrm{D} 22$ & $256949250,3(\mathrm{OK})$ \\
\hline Tumpuan (BA-X) & 31192,679 & 5,36603 & 110,892 & 2019,813 & 5,3 & $6 \mathrm{D} 22$ & $345906606,8(\mathrm{OK})$ \\
\hline Lapangan (BA-X) & 21444,934 & 3,32157 & 68,493 & 1247,547 & 3,3 & $4 \mathrm{D} 22$ & $256949250,3(\mathrm{OK})$ \\
\hline
\end{tabular}

Tabel 8. Pendesainan Tulangan Geser pada Balok Anak Pola III

\begin{tabular}{cccccccc}
\hline & $V_{\text {ud }}$ & $A_{v} / s$ & $A_{v}$ & $s_{1}$ & $s_{2}$ & $s_{3}$ & Dipakai \\
\cline { 2 - 8 } & $\mathrm{N}$ & & $\mathrm{mm}$ & $\mathrm{mm}$ & $\mathrm{mm}$ & $\mathrm{mm}$ & \\
\hline Tumpuan (BA-Y) & 172073,75 & 0,512 & 157 & 306,64 & 232 & 600 & D10-200 \\
\hline Lapangan (BA-Y) & 96443,84 & 0,25 & 157 & 628 & 232 & 600 & D10-230 \\
\hline Tumpuan (BA-Y) & 176160,96 & 0,54 & 157 & 290,741 & 232 & 600 & D10-200 \\
\hline Lapangan (BA-Y) & 98597,55 & 0,25 & 157 & 628 & 232 & 600 & D10-230 \\
\hline
\end{tabular}

Berdasarkan perhitungan yang dilakukan pada modul terbesar diperoleh ketebalan pelat $120 \mathrm{~mm}$. 
Tabel 9. Pendesainan Tulangan untuk Denah Lantai Pola III

\begin{tabular}{ccccccccc}
\hline & $C_{\mathrm{i}}$ & $W_{u}$ & $M_{u}$ & $d$ & $K$ & $a$ & $A_{s, u}$ & \multirow{2}{*}{ Dipakai } \\
\cline { 3 - 8 } & & $\mathrm{Kg}$ & $\mathrm{Kgm}$ & $\mathrm{mm}$ & $\mathrm{MPa}$ & $\mathrm{mm}$ & $\mathrm{mm}^{2}$ & \\
\hline Tumpuan-x & 53,4 & 1449,6 & 1567,525 & 95 & 1,92986 & 7,485 & 454,446 & D10-170 \\
\hline Lapangan-x & 21,8 & 1449,6 & 639,926 & 95 & 0,78784 & 2,982 & 216 & D10-240 \\
\hline Tumpuan-y & 52,4 & 1449,6 & 1538,171 & 95 & 1,89372 & 7,338 & 445,521 & D10-170 \\
\hline Lapangan-y & 21 & 1449,6 & 616,442 & 85 & 0,94801 & 3,221 & 216 & D10-240 \\
\hline
\end{tabular}

Tabel 10. Kontrol Momen dan Gaya Geser

\begin{tabular}{cccccccc}
\hline & $A_{s \text { baru }}$ & $a$ & $\begin{array}{c}\phi M_{n} \\
\left(M_{u} \leq \phi M_{n}\right)\end{array}$ & $L_{n}$ & $q_{u}$ & $V_{u}$ & $\begin{array}{c}\phi V_{c} \\
\left(V_{u} \leq \phi V_{c}\right)\end{array}$ \\
\cline { 2 - 8 } & $\mathrm{mm}^{2}$ & $\mathrm{~mm}$ & $\mathrm{Kgm}$ & $\mathrm{mm}$ & $\mathrm{kg}$ & $\mathrm{Kg}$ & $\mathrm{Kg}$ \\
\hline Tumpuan-x & 461,765 & 7,606 & $1591,818(\mathrm{OK})$ & 4200 & 1449,6 & 3044,16 & $780504,64(\mathrm{OK})$ \\
\hline Tumpuan-y & 461,765 & 7,606 & $1591,818(\mathrm{OK})$ & 4150 & 1449,6 & 3007,92 & $780504,64(\mathrm{OK})$ \\
\hline
\end{tabular}

\section{Pembahasan}

Berdasarkan hasil perhitungan di atas diketahui bahwa penempatan balok anak mempengaruhi tebal pelat. Jika pelat lantai gedung Toko Satu Sama direncanakan tanpa memakai balok anak (pola I) maka tebal pelat yang dipakai akan menjadi $220 \mathrm{~mm}$. Jika pelat lantai tersebut direncanakan menggunakan satu balok anak searah sumbu-y (pola II) maka tebal pelat akan menjadi $180 \mathrm{~mm}$. Jika pelat lantai tersebut didesain dengan menggunakan satu balok anak searah-x dan ditambah dengan satu balok anak arah-y maka tebal pelat akan menjadi $120 \mathrm{~mm}$. Jika dibandingkan dengan tebal pelat rencana dari konsultan perencana tingkat efisiensi pola III dapat dihitung dengan cara sebagai berikut:

$$
\text { Efisiensi pelat }=\frac{(150-120)}{150} \times 100=20 \%
$$

Perbedaan pola penempatan balok anak juga berpengaruh pada kebutuhan material beton dan baja tulangan yang dipakai.

- Pola II dengan tebal pelat $180 \mathrm{~mm}$ dan dimensi balok anak $30 / 65 \mathrm{~cm}$ membutuhan beton sebanyak $=$ $(0,180 \times 9,2 \times 9)+(0,30 \times 0,47 \times 9)=16,173 \mathrm{~m} 3$.

- Pola III dengan tebal pelat $120 \mathrm{~mm}$ terpasang balok anak dan dimensi 30/55 $\mathrm{cm}$ membutuhan beton sebanyak $=(0,120 \times 9,2 \times 9)+(0,30 \times 0,43 \times 9,2)+(0,30 \times 0,43 \times 9)=12,284 \mathrm{~m} 3$.

- Pola penempatan balok anak arah-x (pola konsultan perencana) dengan tebal pelat $150 \mathrm{~mm}$ dan balok anak berdimensi $35 / 80 \mathrm{~cm}$ membutuhkan beton sebanyak $=(0,150 \times 9,2 \times 9)+(0,35 \times 0,65 \times 9,2)=$ $14,513 \mathrm{~m} 3$.

Dari data tersebut dapat diketahui bahwa pola penempatan balok anak arah-x dan arah-y memiliki kebutuhan beton yang paling sedikit.

$$
\text { Efisiensi kebutuhan beton }=\frac{(14,513-12,284)}{14,513} \times 100=15,359 \%
$$

Dari segi kebutuhan material tulangan, kebutuhan tulangan balok anak denah pola konsultan memiliki kebutuhan besi yang paling sedikit. Untuk tulangan pelat lantai, jarak tulangan pada pola II dan pola III lebih 
renggang dibandingkan dengan pola dari konsultan (balok anak arah-x). Hal itu menunjukkan bahwa kebutuhan tulangan pelat lantai pola II dan III lebih sedikit.

\section{KESIMPULAN}

Beberapa kesimpulan yang dapat ditarik ialah sebagai berikut:

1. Dari ketiga pola tersebut diperoleh tebal pelat yang paling efisien ialah $120 \mathrm{~mm}$ dengan pola penempatan balok anak arah-x dan arah-y (pola III) dengan tingkat efisiensi sebesar $20 \%$.

2. Pola penempatan balok anak yang menghasilkan kebutuhan beton yang paling sedikit ialah pola III dengan volume beton $12,284 \mathrm{~m}^{3}$ yang memiliki efisiensi sebesar $15,359 \%$. Namun pola III memiliki kebutuhan tulangan balok anak yang lebih banyak.

\section{DAFTAR PUSTAKA}

[1] Vis, W., \& Kusuma, G. (1993). Dasar-dasar Perencanaan Beton Bertulang. Jakarta: Erlangga.

[2] Setiyadi, B., \& Pradoto, H. (1996). Studi Komparasi Perilaku Balok Grid dan Balok Konvensional pada Struktur Pelat Lantai Bangunan Gedung. Skripsi: Fakultas Teknik Sipil dan Perencanaan. Universitas Islam Indonesia.

[3] Purnomo, A. D., \& Sugiharjo. (2000). Analisis Pengaruh Penempatan Balok Anak terhadap Portal Komposit Baja-Beton dengan Metode LRFD'86. Skripsi: Fakultas Teknik Sipil dan Perencanaan. Universitas Islam Indonesia.

[4] Tistogondo, J. (2005). Studi Perbandingan Penggunaan Balok Anak Konstruksi Propped pada Bangunan Tingkat Dua dengan Variasi Jarak Balok dan Portal dari Segi Teknik dan Biaya. NEUTRON: Vol 5. No 1 .

[5] Wibawa, N. P., \& Kismana. (2005). Balok Anak Sebagai Beban Terpusat dan Sebagai Struktur Monolit, dan Pengaruhnya Terhadap Respon Struktur Beton Bertulang. Skripsi: Fakultas Teknik Sipil dan Perencanaan. Universitas Islam Indonesia.

[6] Budiyawan, M., \& Yulandaru, P. (2006). Pengaruh Variasi Peletakan Balok Anak terhadap Volume Struktur Pelat dan Balok. Skripsi: Fakultas Teknik Sipil dan Perencanaan. Universitas Islam Indonesia.

[7] Setiawan, E. d. (2015). Studi Penggunaan Balok Anak pada Struktur Pelat Beton Bertulang. JeLAST.

[8] Chilk, R. S. (2019). Pengaruh Balok Anak terhadap Ketebalan Pelat Lantai Masjid Lheu Kabupaten Aceh Besar. Skripsi: Fakultas Teknik. Universitas Mumammadiyah Aceh.

[9] Partama, I. G. (2017). Penentuan Tebal Pelat Lantai Gedung yang Ditumpu pada Keempat Sisinya sesuai SNI 2847:2013. GRADIEN: Vol 9. No 1.

[10] Majid, A. N. (2019). Analisis Pengaruh Dimensi Balok Anak Terhadap Momen Lentur pada Pelat dengan Metode Amplop dan Metode Elemen HIngga. JRSDD: Vol 7. No 1.

[11] Tahan. (2019). Pengaruh Kekuatan Balok Induk Terhadap Dimensi Balok Anak pada Beton Bertulang. Media Ilmiah Teknik Sipil. 